\title{
From Mesolithic to Early Christianity: The Development of the Ritual Complex in the Northern Part of Lake Biržulis (Lithuania) According to Archaeological, Linguistic and Historical Research
}

\author{
Adomas Butrimas \\ Vilnius Academy of Arts, Lithuania
}

Copyright $(2017$ by authors, all rights reserved. Authors agree that this article remains permanently open access under the terms of the Creative Commons Attribution License 4.0 International License

\begin{abstract}
Several ritual complexes are known in Europe, the origins of which reach back to the Stone Age, and their chain of development includes the metal ages or even the period of official conversion to Christianity, such as Stonehenge (England), Newgrange (Ireland), and Alvastra near Lake Tåkern (Sweden). Such complexes stretching across a long chronological period are known also from western Lithuania, in Žemaitija (Samogitia). On the basis of archaeological, linguistic and historical research we attempt in this paper to reconstruct the development of the Donkalnis and Spiginas Mesolithic-Neolithic cemeteries, sacrificial hearths, and funerary feast sites, which date from the middle Mesolithic period to historical times. We have selected a very narrow area along the shores of Lake Biržulis in western Lithuania. During the Mesolithic and Neolithic periods this was an $800 \mathrm{~m}$. east-west-oriented area, where discoveries have been made of settlements, sacrificial and burial sites, and a seer's grave. On the basis of archaeological and ethnological Indo-European studies and the earliest historical sources (namely, the land registers of the bishops of Žemaitija from 1421-1662) we study the later period from the early metal ages to the very late official conversion of the area to Christianity in 1413, during which time the area spread 1,000 m. westwards. An attempt is made to reconstruct the sacralisation and monumentalisation of this space over almost 7,500 years from 5980 B.C. to A.D. 1413-1421.
\end{abstract}

Keywords Mesolithic, Neolithic, Sacrificial and Burial Sites, Conversion to Christianity, Sacralisation And Monumentalisation, Lithuania

\section{Introduction}

Throughout Europe only a few stone-age ritual complexes have been studied in depth and presented finely to tourists.
Stonehenge is an exceptional site of such past magnificence visited by millions of tourists from around the world. It was built over several thousand years (its first traces date to the Mesolithic, the last to the Bronze Age), renewed with various building materials (earth, wooden stakes, standing stones) and its purpose changed over time. Stonehenge had various functions as temple, ritual ceremonial centre, burial site, and a place for calendar and other rituals [1]. This complex comprises more than a dozen monuments dating to various periods which are connected by special tracks marked by mounds or wooden posts, known as avenues. These avenues, mounds and wooden and stone temples are spread over a site to the north of the River Avon. Scholars do not doubt the special role the river played in the existence of this complex. The site has been subject to research and interpretation for more than 350 years and this continues today. The complex now stretches over an area more than a dozen square kilometres in size and its chronological boundaries have been divided into eight phases from 3005-2915 BC to 1630-1520 BC [2, 3].

Similar ritual complex sites used over several millennia as calendar monuments, temples and burial places exist at Newgrange (Ireland) and Alvastra near Lake Tåkern in Sweden, the closest such extensive complex to Lithuania. It comprises stone-age lakeside peat settlements, bronze-age barrows, hill-forts from the Great Migrations' Period and early Christian church crypt burials. The early development of this complex culminated with the building of a monastery on the site in 1143 .

Research at the Donkalnis and Spiginas stone-age complexes (Fig. 1) has revealed many subtle and unexpected facts about grave fitting, symbolic and sacrificial hearths, and funeral feasts which show that particularly complex burial rituals existed as early as the Mesolithic period. Bronze Age offering sites and hills stood nearby at Širmè hill-fort, and the Žemaitijan territory of Medininkai developed here in the 13-14th centuries [4]. Since A.D. 1370 
written sources mention Viržuvènai, and Lake Biržulis, the part of which lying around the River Virvytė was granted to the first Žemaitijan bishop, Mathias, and his cathedral chapter by Grand Duke Vytautas on 22 June 1421 [5]. Thus charters from later rulers (1547), documents from wardens of the lake (Jeronimas Chodkevičius (1547), etc.), and the 1637, 1638 and 1662 inventories of the bishop's Viržuvènai manor, where many now non-existent toponyms and hydronyms from the area around Biržulis were recorded [6,7], represent the most important witnesses of the further historical development of this complex. During archaeological expeditions to Biržulis (1978-1992), many place names were recorded, including the lake's haul names, and various methods have been employed to study the evolution of the lake's environment and analyze archaeological findings (especially through radiocarbon dating, use-wear analysis, genetics, and palaeogeographical and bioarchaeological studies). All these data have revealed considerable information about this complex. Gradually the centre of a unique complex was uncovered, which occupied only a small, approximately 800 metres-long part of the northern shores of Lake Biržulis. After multidisciplinary research, various aspects of local ceremonial life, such as burials, memory of the dead, funeral practices, and feasts, were revealed gradually at this unique complex. If we add data from written sources, and results from mythological and linguistic research (especially hydronyms and toponyms), a unique multi-millennial tradition begins to become clear [8-14]. We came across a complicated ceremonial site, possibly the longest known from eastern Europe, where the first historical evidence was left by hunters and fishermen buried in Donkalnis (7-6 millennia BC), whilst later, in the 5-3 millennia BC, traditions were continued by Narva culture hunters, gatherers and fishermen. During prehistoric times the communities which dwelled in this place strove to maintain their varied natural resources, flora and fauna with the help of their traditions and religious practices. Their physical activity was greater and their diet much more varied than was the case with agricultural communities. Later, from at least the third millennium $\mathrm{BC}$, these lands were inhabited by Corded Ware and Globular Amphorae cultures - old Indo-Europeans, who differed from earlier local inhabitants in their genetics and use of agricultural traditions. In the palaeolithic period Lake Biržulis was not located near main routes, which are very characteristic of coastal regions, or main rivers (Nemunas, Dauguva), and therefore the new settlers still used all natural food sources (fish, animals, plants) from the Biržulis micro-region. It was they who watched over the great Neolithic sacrificial hearth at Donkalnis for hundreds of years, and later Bronze Age pottery became important in the formation of the first Baltic tribes (aestii). The later history of the development of these communities was continued by Curonian and Žemaitijan tribes, which lived on opposite banks of the Druja River. The boundaries of lands of these tribes are marked not only by archaeological sites and toponyms (Kuršiai, Kuršeliai, Kuršupalis, etc.), but also by the ancient boundaries of the parishes of Janapolè and Pavandenè. In these burial grounds archaeologists have found an abundant number of weapons, which reveal not only the occurrence of local conflicts, but also the need for locals to defend themselves from attack by the Sword Brethren and the Teutonic Order, which invaded these lands in the 13th century. Dwelling places were not only chosen by lakes and rivers, isthmuses, and the broader, sloping shores of Lake Biržulis but also on the moraine hills around the lake, where remnants of the ditches, mounds, platforms of hillforts with their high, steep slopes can be seen to this day. The great castles of the land of Medininkai concentrated around Lake Biržulis and the confluences of the River Virvytė - Sprūdè (Šaukštelis), Moteraitis (Burbiškiai), two Girgždūte hill-fort, Širmè hill near Janapolè, and the Sèbai and Šatrija hill-forts bear witness to the particular importance of this land in the history of Žemaitija.

The site itself is considerably closer to northern shores of Lake Biržulis and the Virvyte confluence. In this rather small area a whole ritual complex formed over several millennia. In addition to the oldest part of it - Donkalnis, the old late Neolithic and Bronze Age settlements of Skirmatine, Gaigalinè I and II, and Širmè hill are surrounded by Stabinè village, Stabakulis field, and Alkaliu meadows. A Bronze Age offering site with striking bronze artefacts is located about $800 \mathrm{~m}$ to the west of Širmè hill, near the inflow of the Virvytè in Patilčiai village. Between Donkalnis and Širmè hill stands the sacrificial hill of Janapole, which probably dates to the early Middlle Ages. This chain of religious sites was completed after the official Conversion of Žemaitija in 1413, with the Žemaitijan bishop's manor, and Janapolè parish and church.

In the mid-twentieth century structural anthropologists such as Claude Lévi-Strauss researched human lifestyles and attempted to connect ways of thought and behavior determined by myth and ritual. The repetition of formal actions and phrases intended to lead to an unknown state of being and the insuring of symbolic order are part of community training. Rituals change, but the structure remains recognizable and members of a tribe taking part in shared rituals strengthened their community identity $[15,16]$. This process can be seen in the Žemaitijan context too.

\section{Methodology}

The methodological aspects include three main points of analysis:

- the analysis of the archaeological-ritual complex in the Northern part of Lake Biržulis, based on archaeological excavation material, radiocarbon dating, genetic and paleo-geographical and bio-archaeological studies;

- linguistic and etymological analysis of place names, recorded during expeditions in the area around Lake Biržulis, 1978-1992;

- analysis of written sources and mythology (documents from 1370, 1421, 1662). 
Multidisciplinary research resulted in the reconstruction of a unique ceremonial complex, one of the most long-lived in Eastern Europe.

\section{Biržulis and Burtnieks: Special Lakes for the Oldest Burial Grounds in the Eastern Baltic}

\subsection{Ethimological Meaning of the Hydronims "Biržulis" and "Burtnieks"}

The sites of the oldest eastern Baltic stone-age cemeteries and ritual complexes at Spiginas, Donkalnis and Zvejnieki (northwestern Latvia) were not chosen by accident. Spiginas and Donkalnis were established on islands in Lake Biržulis (West Lithuania) (Fig. 2 and 3). Based on associated artefacts and the radiocarbon dating of human bones from the cemeteries it was concluded that these complexes were in use for a period of more than four millennia (6377-to 2290 $\mathrm{BC})$. The meaning of Lake Biržulis in Indo-European languages is metaphorical, signifying "ritually clean", "innocent" in old Indo-European [17]. Some parallels may be drawn with the famous Zvejnieki cemetery in Northern Latvia. The name of Lake Burtnieku, where Zvejnieki is located, in translation means "Sorcerer's Lake". In the Baltic languages, words with the root burt- (burti, burtas, burtininkas) are abundant. They occur in place names and written sources in Latvian, Lithuanian, and Old Prussian, and only in very rare cases - in Slavonic languages. Sorcerers' names are also known - Burtai, Burtonei, Burtons, Burtones, Burteninki, Burtniker, Burtinikie - in the work of John Malalas, Jan Łasicki, and Matthäus Pretorius, and in Martynas Mažvydas's Catechism (1547). These words are related with magic, sorcerers, spells, and fortune-telling. Later Christianity combatted witchcraft and magic, which even as late as the 18th century were blamed for all manner of damage to humans, animals and nature [9, 18, 19]. Since the occurrence of this word is detectable almost only in the Baltic region [12], it leads one to believe, that the burial grounds in Zvejnieki, Donkalnis and Spiginas on their lake islands and in other vicinities, and the sacral processes associated with them, may have begun during the seventh millennium BC, and developed until the regions converted to Christianity. Study of the origins of the words burti, burtas could perhaps lead linguists to proto-Indo-European local cultures (for example, Narva culture).

\subsection{Ethimological Meaning of the Hydronims "Ruja" and "Druja"}

We also note the linguistic parallel between the areas around Lakes Biržulis and Zvejnieki, namely that the River Ruja at Lake Burtnieku (Zvejnieki cemetery) and the River
Druja at Lake Biržulis (Donkalnis cemetery) are connected semantically with flowing (Druja) or standing (Rūja) water. Aleksandras Vanagas explains these hydronyms very simply. On the basis of the work of Jan Endzelyn, Hans Krahe, Kazimieras Kuzavinas, and Vladimir Toporov, he links the name of the River Druja in the vicinity of Varniai and Biržulis and the names of the Latvian River Druve and Lake Druvas-ezars, with the ancient Indian words draváh (run, running) and draváti (run, flow) [14]. He links the hydronym Ruja with standing, stagnant water. A river by the same name is known from Troškūnai parish, whilst marshland of the same name lies near Raguva. Three close hydronyms are known in Latvia - Rüja, Rü-jupe, Rüjas. Perhaps a hydronym of similar origin can be found in Kaszuby (raja "swamp, mud"), where Baltic names abound. Kazimieras Būga and Marta Rudzyte thought that this name is a loanword from the Finno-Ugric languages $[20,21]$. However, the geographical prevalence of this place name in Baltic and Finno-Ugric areas, and the fact that it is found near Zvejnieki burial ground in Latvia, the oldest and largest such site in Eastern Europe, known since the Mesolithic, would allow us to hypothesise that the origin of this word might derive from ancient European (proto-Indo-European) cultures. As the newest genetic research shows, these cultures migrated towards the North, through Baltic and Finno-Ugric lands as far as the Saami areas of Scandinavia. The migration trajectory can be seen through the ancient holders of U5 and U4 haplogroups: Mediterranean Sea coast inhabitants have $1-5 \%$ of these groups, in the rest of Europe (including Lithuania) these haplogroups are spread among $5-7 \%$ of the population, whilst in Scandinavia the occurrence of these groups among the Saami is as high as even $40 \%$ [22]. Such holders of the latter haplogroups were absent from early agricultural societies. This signifies the arrival in the area of new anthropologically different communities with different haplogroups.

Particular attention should be devoted to hydronym Druja. According to the specialists in the ancient Prussian language Vladimir Toporov and Vytautas Mažiulis, words with root $d r u v$-, $d r \bar{u} v$ - can mean "to believe, have faith, be strong, have strong faith" [11, 12]. Therefore, the river Druja near what is now Donkalnis could be further evidence of a millennial tradition of burial, funeral pits, and sacrificial hearths. The occurrence of Druv- meaning "to believe, have faith" in Baltic and Germanic languages may demonstrate ancient contacts between these languages, and the second phase of special sacralization of this place, where its bisyllabic name, Don-kalnis, in ancient Indo-European may have meant "hill (kalnas) in the water (don)".

\section{3. "Biržulis" Name in the Written Sources}

More attention should be paid to the name of Lake Biržulis. It was mentioned for the first time in written sources by the famous $16^{\text {th }}$ century diplomat and Calvinist divine, Jan Łasicki, in his treatise "On the gods of the Žemaitijans, other Sarmatians, and false Christians", published in 1615. He 
referred to his predecessor Jokūbas Laskauskas, who was King Sigismund Augustus' surveyor of royal estates in Žemaitija in 1534 and 1551-63, and a student of Žemaitijan culture. His long period of working as royal surveyor of the historical areas of Plateliai, Gargždai, Josvainiai, Šiaudinè, Ariogala, and Karšuva enabled him to communicate with locals and to record much local data. This activity which lasted more than 14 years might be regarded in modern parlance as an expedition and the first to last so long in Žemaitija. On the basis of Jokūbas Laskauskas, Lasicki wrote: "They are most unwilling to tell Christians what Salaus, Szlotrazis, Tiklis, Birzulis, Siriczus, Duvargonth, Klamals, Atlaibos and other similar gods do. They are supposedly people's helpers, and therefore it is necessary to turn to them" [9]. The work of Jan Łasicki was regarded as "hardly reliable" by Aleksander Brückner [8]. W. Jaskiewicz, who wrote his dissertation about Jan Łasicki's work, mentions that Lake Biržulis near Varniai could have been a mythical image, representing a figure marking out woodland [10]. Nowadays, the culturologist Vytautas Ališauskas is interested in the study of Jan Łasicki. Earlier, attention was paid to the word Béržuvis by famous Indo-European researchers. On the basis of data from the Hattian, Thracian, Baltic and Slavonic languages, they were inclined to assign a meaning of "clear" to this word, whilst its metaphorical meaning would be "ritually clean, virgin" [17]. Biržulis was probably very special from the ancient Indo-European culture period onwards and related to ceremonial rites on the lake's northern shore. After in-depth study it becomes unsurprising that this lake was mentioned as a god in Jan Lasicki's $16^{\text {th }}$-century work.

It seems that interpretations of the words Spiginas, Spigino ragas should also be expanded. Frost and the sun are not the only things that can spiginti (glare). Spiginas Horn, as well as the Spiginas island burial ground, where graves dating back to the 7-3 millennia $\mathrm{BC}$ were found, ends in the southern part of Biržulis Lake. The world of the dead on the island was separated from that of the living by water. In his Prussian etymological dictionary Vytautas Mažiulis explains that the word spigsna means "washing", "to sprinkle". No doubt in the Biržulis case the washing of the deceased may have been done during the corpse's final journey to the island. Spiginas is a word that takes on a new meaning.

\subsection{Donkalnis Stone Age Cemetery and Offering Place}

The islands of Donkalnis (of which the old Indo-European meaning is "hill in the water") and Spiginas, where stone-age people were buried, are really very clearly visible in the landscape and for local people they may have been socially very important, such as for burying the dead, holding ritual feasts, and later during the Neolithic - as an offering place. The furnishing of both cemeteries on the Biržulis islands of Spiginas and Donkalnis sited 200-300 m away from the peninsulas also can be seen from peninsula camps and settlements - both in Mesolithic and Neolithic times and this reveals much of burial customs [23]. The cemeteries on these islands and the on Oleneostrov in Onega Lake, Zvejnieki in Lake Burtnieku and certain Scandinavian burial grounds complement our data $[24,25]$. This practice survived in the eastern Baltic region during the Neolithic period.

This may have determined the slow monumentalisation of these two sites, which reached a stage where they became most visible and known to nearby communities. The visual effect of these cemetery and ritual complexes was very striking; the same cannot be said of all stone-age ritual and cemetery sites in the Baltic Region. We deduce that space, place and landscape in the Biržulis area have always held a broad range of emotions and meanings throughout a long period of time that may be difficult to specify. The Donkalnis centre had particular social significance containing local communities, a curious outcrop of land like the horn-shaped Spiginas escarpment, which was also a clear site dominating the local landscape. Donkalnis became such a dominant feature not only because people were buried here from 6377-6221 to 2880-2470 BC, albeit sometimes with considerable intervals, but also because regular ritual activities took place there such as burial ceremonies, feasts in honour of the dead (Mesolithic period) and later sacrifices which were offered in the huge sacrificial hearth (Neolithic and early Metal period) (Fig. 4). Members of local communities taking part in shared rituals strengthen their common identity, distinguishing themselves from alien identities. The landscape also offers them a vernacular entry to activate specific movements, actions, narratives, signs and rituals and those activities can modify a place and local landscape.

This paper also seeks to show how in a particularly compact environment (in a narrow 1,600 m strip of land on the northern shore of Lake Biržulis) these connections remained unbroken, deepening over time and changing to become important ritual sites during the Metals' Period, even as late as the 1413 official conversion of Žemaitija to Christianity. The sites' chronology can be ordered preliminarily as follows:

Donkalnis stone-age burials (Mesolithic) graves and the symmetrical and symbolic placement of grave goods animal teeth - in double grave No 2 (with closest analogies in Oleneostrov): a necklace of 27 teeth was found in the grave around $3-5 \mathrm{~cm}$ from the skull). A further two bored teeth were found placed specially root-upwards on the eyes (one tooth on each eye). Two teeth were placed in each ear, thereby maintaining the symmetry of the whole head decoration and two large elk front teeth were placed with their roots deep in nostrils. Such symmetrical decoration of the head had a symbolic meaning and reveals the social status of the person buried here. The woman buried with bent legs lying to the man's right also bore symbolic significance. At the northern edge of the grave was a small mound of knapped stones measuring $50 \times 60 \mathrm{~cm}$ and sprinkled with ruddy ochre which was probably a symbolic heart. Perhaps this double grave should be regarded as the resting place of a soothsayer and his companion on the journey to the hereafter. Grave 2 is dated 6377-6221 BC (Fig. 5). 
The Donkalnis (Mesolithic) funeral feast pit filled with red ochre raises another little-discussed issue, namely that of funeral feasting in memory of the dead. The ritual pits that have been discovered suggest that there were places on the cemetery territory or nearby, that were designed for remembering the dead. Those ceremonial pits were filled with red ochre along with small animal bones, fishbone fragments, large pike jawbones and an elk-tooth pendant (Donkalnis) (Fig. 6).

\section{Donkalnis and to the West from it: Sacral Places Development from the End of Neolithic to Žemaitijan Baptism}

\subsection{Archaeological Sites from the Neolithic and Bronze Age}

Archaeological excavation of Donkalnis and the Stone-Age and Bronze-Age sites situated to the west of it (Gaigaline I and II, Skirmantine, etc.), references to offering places, studies of archaeological and land drainage results, place names and historical sources have revealed that the special ritual complex occupies and area of approximately $1.5 \mathrm{~km}$. This is related not only with the oldest heritage which we have discussed, but also with new settlers, ideas, agriculture, and ritual traditions. Perhaps it is related with more complicated sacrificial rituals, the chronological development of which is very hard to reconstruct.

First of all, this area was inhabited by new people of different phenological types and genes groups, with different burial traditions $[26,27,28]$. From Central Europe they brought flat-bottomed, mostly cord-ware ornamented pots, new flint technology (triangle flat-retouched arrow- and spearheads), animal husbandry (sheep and goats), whilst Globular Amphorae culture brought new amber manufacturing technology (the idea of solar symbols, and the cruciform decoration of amber discs). Husbandry and small cultivation brought more stability to the Biržulis settlements. The need to adapt to environment led to the emergence of local traditions. Donkalnis and Spiginas became burial grounds where the newcomers also buried their dead. It is worth noting that they did not pour ochre into burials, but in Donkalnis they established an offering pit whose specifically new feature was a great hearth, which measures $9 \mathrm{~m}$. long east to west and is $6 \mathrm{~m}$. wide north to south. At its deepest point it reaches $110 \mathrm{~cm}$ from the surface. In all, the multiple-use sacrificial hearth covers an area of $28 \mathrm{~m}^{2}$. Smaller, oval shape hearths were detected in several places in the northern part of the sacrificial site. A similar long hearth was used in the Neolithic settlement at Nida [29]. Pottery, and flint tools were found in the Donkalnis sacrificial pit. Potsherds from a later period were also found, and these can be dated to the beginning of the Bronze Age [23]. Very similar ornamented pottery is ascribed to Trzciniec or Ivenian cultures. There are no separate settlements in the Biržulis region with this type of pottery. However, these fragments may indicate contacts between the Masurian Lakeland and Western Lithuania at some period. The most significance symbols of this pottery are the pot edges ornamented with counters and lines [30]. This Biržulis region pottery type was studied by Agnè Žilinskaite [31]. In a light gravel layer approx. 1-3 m. south of the hearth traces began to emerge of six dark ovular stakes. These stakes may have been related to some kind of construction; there may also be possible connections with late-Neolithic burials. The great (Neolithic) Donkalnis sacrificial hearth was built most probably in the Neolithic period and used until the Early Metal Age period, very likely considerably later than the Mesolithic graves and ritual pits with red ochre. Pottery from the late Neolithic (Corded Ware culture) and even from much later periods (Trzyniec and other Central Europe forest zones) was also found [31]. The great multiple-use sacrificial hearth, measuring $9 \mathrm{~m}$ long (east to west) and $6 \mathrm{~m}$ wide (north-south) and $110 \mathrm{~cm}$ deep at its deepest point, existed over a long period, possibly as late as the Early Metal Age (Fig. 7). The Late Neolithic grave 7 from this period in Donkalnis is dated $4290 \pm 35$ BP.

The third stage in the development of this ensemble is connected with research into the early-Bronze-Age Gaigaline 1 and 2 settlements and the Bronze-Age sacrificial site in the village of Patilčiai (1700-1100 B.C.). A Bronze-Age offering site, at the village of Patilčiai in the upper reaches of the River Virvyte had a significant meaning as offering place in Donkalnis. In 1933, when land drainage works were in progress, M. Mikalauskas marked unique findings in his plan: a long bronze pin and a Nortikenai type axe. These artefacts are rare in the territory of Lithuania. As examples from foreign countries show, this place was a Bronze-Age offering site. Many similar impressive sites with various rich sacrifices are known in Scandinavia. Flowing river water in ancient Europe cultures was imagined as an intermediary between the worlds of the living and the dead.

\subsection{The Toponyms Connected with Archaeological Monuments}

This period also covers late-Neolithic and early-Bronze-Age settlement toponyms:

Alkalių pievos (Offering fields) (Early Metals' Period).

Stabakulio laukas (Idol stone field) (mentioned in written sources - the 1662 Inventory of land belonging to the bishop of Žemaitija.

Stabinès kaimas (Idol village) - a village with only one farm, which survived until the present, including the hauling of nets by fishermen on the lake, which is known as Po Alka ("for the temple" "for the Offering hill") (Fig. 8).

It appears that the Viržuvenai (Janapolè) temple-hill area, which dominates its surroundings and can be seen from afar, marks the end of sites with sacral names and it is here that the fourth stage begins with early-mediaeval archaeological monuments.

Viržuvenai temple-hill (at least until the official 
conversion of Žemaitija in 1413). Perhaps the hill-fort of Širmès hill, which can be connected with the beginning of the parish village of Viržuvenai, mentioned in written sources from 1421 is connected with this period. Later
Viržuvenai was renamed Janapolè after the Žemaitijan bishop Jonas Lopacinskis (XVIII c.).

After this we present a table of the four stages of local sacralisation process of the Northern shores of Lake Biržulis:



Figure 1. The location of Donkalnis sacrificial site and Lake Biržulis (West Lithuania). Illustration by R. Spelskytė 

of Lake Biržulis (Lithuania) According to Archaeological, Linguistic and Historical Research

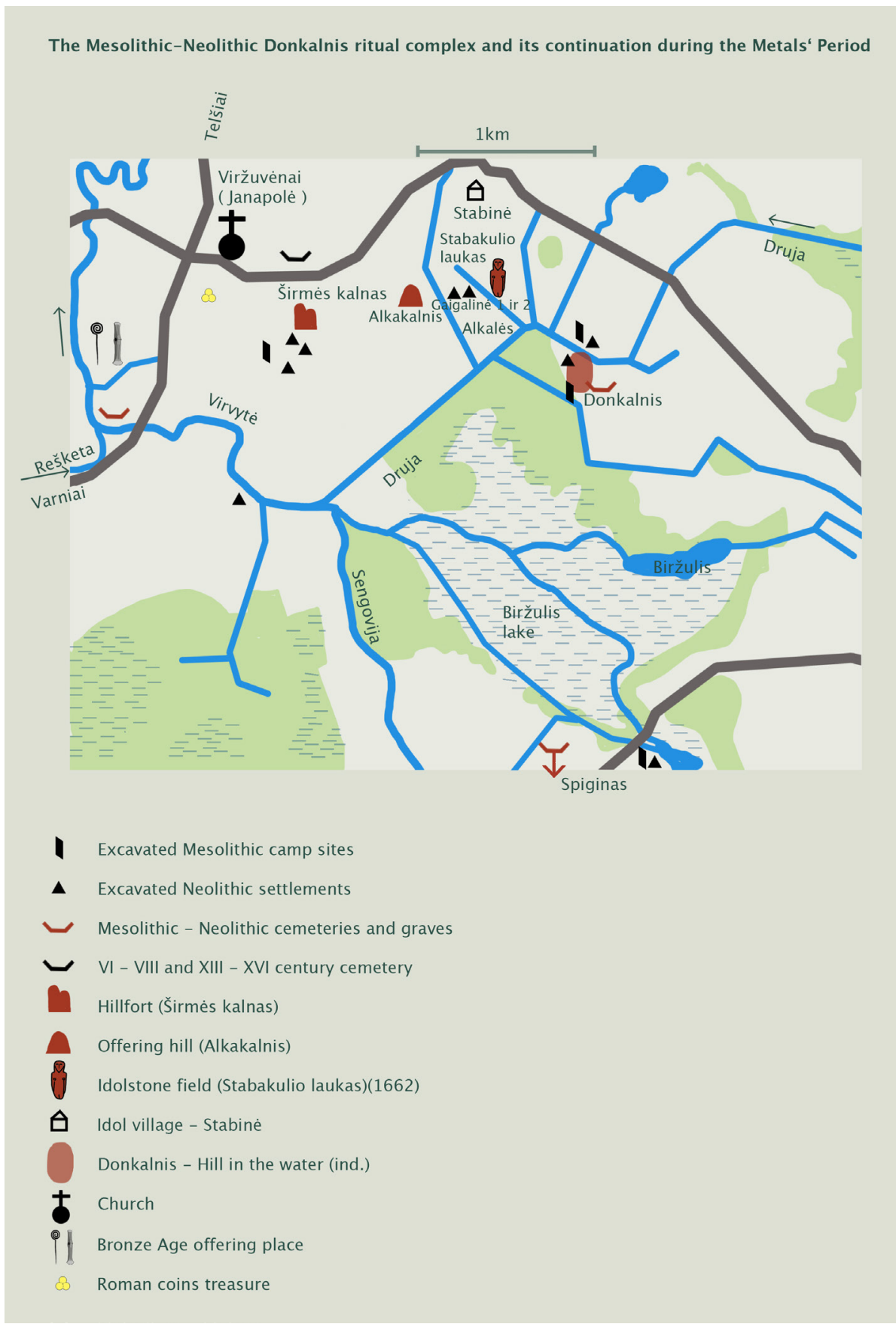

Figure 2. The Mesolithic-Neolithic Donkalnis ritual complex and its development during Metal's Period. Illustration by R. Spelskyte 
Site Plan of Donkalnis Excavation: graves,

large heart and sacrificial pits

(Mesolithic - Neolithic)
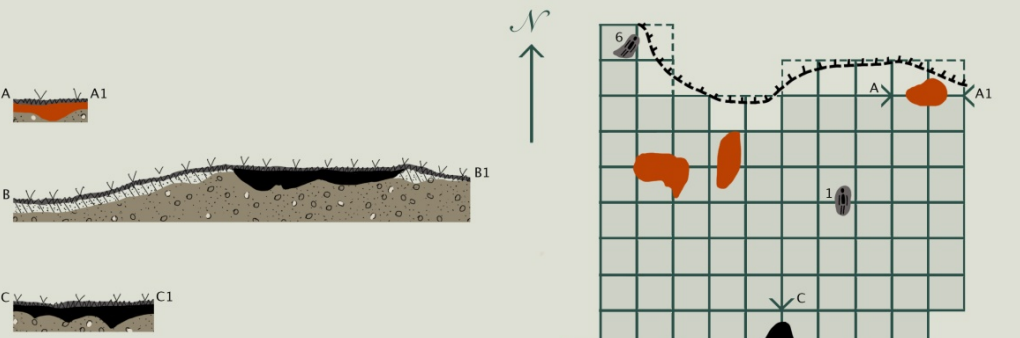

- Large heart from Neolithic Early Bronze sacrificial site

$\because 2$ - Poles

3 - Sacrificial pit (funeral feast pits) Mesolithic

4 - Turf

Anili 5 - Cultural layer

- 6 - Variable grade gravel

7 -Sand

A - A1 8 - East - west cross section of ochre filled sacrificial pit (funeral feast pit) Mesolithic

ــ. 9 - Gravel mining area

B-B1: C - C1 - Cross sections across the "Great Neolithic heart"

- 10 - Mesolithic graves

$\Leftrightarrow 11$ - Neolithic graves

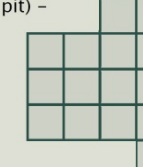

\begin{tabular}{|l}
\hline \\
\hline \\
\hline
\end{tabular}

$\mid 2 m$

Figure 3. Site Plan of Donkalnis Excavations graves, Mesolithic sacrificial pits and large hearth. Illustration by R. Spelskyte 




Figure 4. East-west Section of Mesolithic ochre-filled funeral feast hearth near the edge of the gravel quarry. Photo by S. Butrimienè 


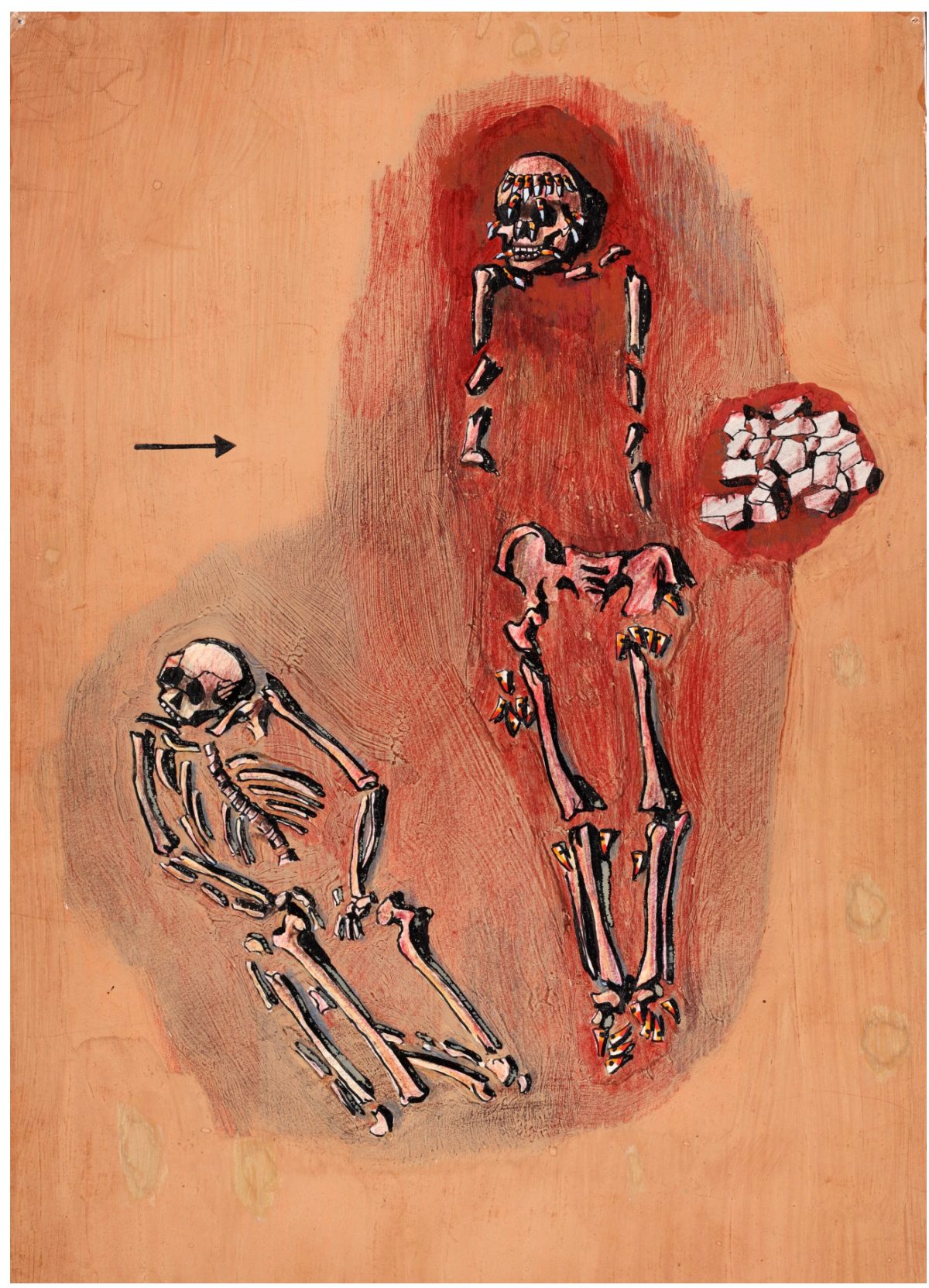

Figure 5. Double red-ochre sprinkled grave (No 2 and 3) of soothsayer and grave of female with bent legs at Donkalnis. Sketch reconstruction by R. Krupauskas 


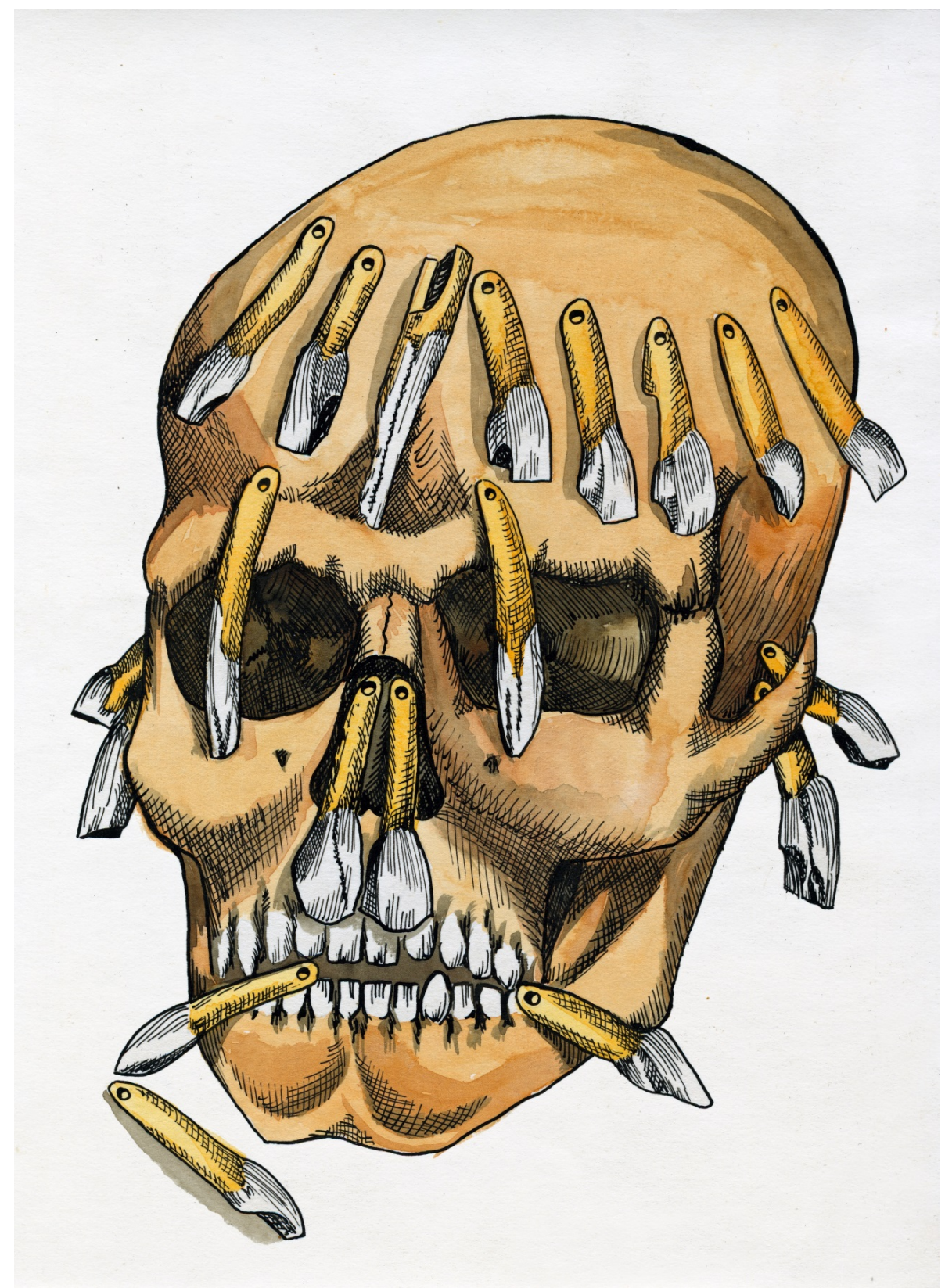

Figure 6. Soothsayer's skull from Donkalnis Grave 2. Sketch of reconstruction by R. Tautavičiūtè 


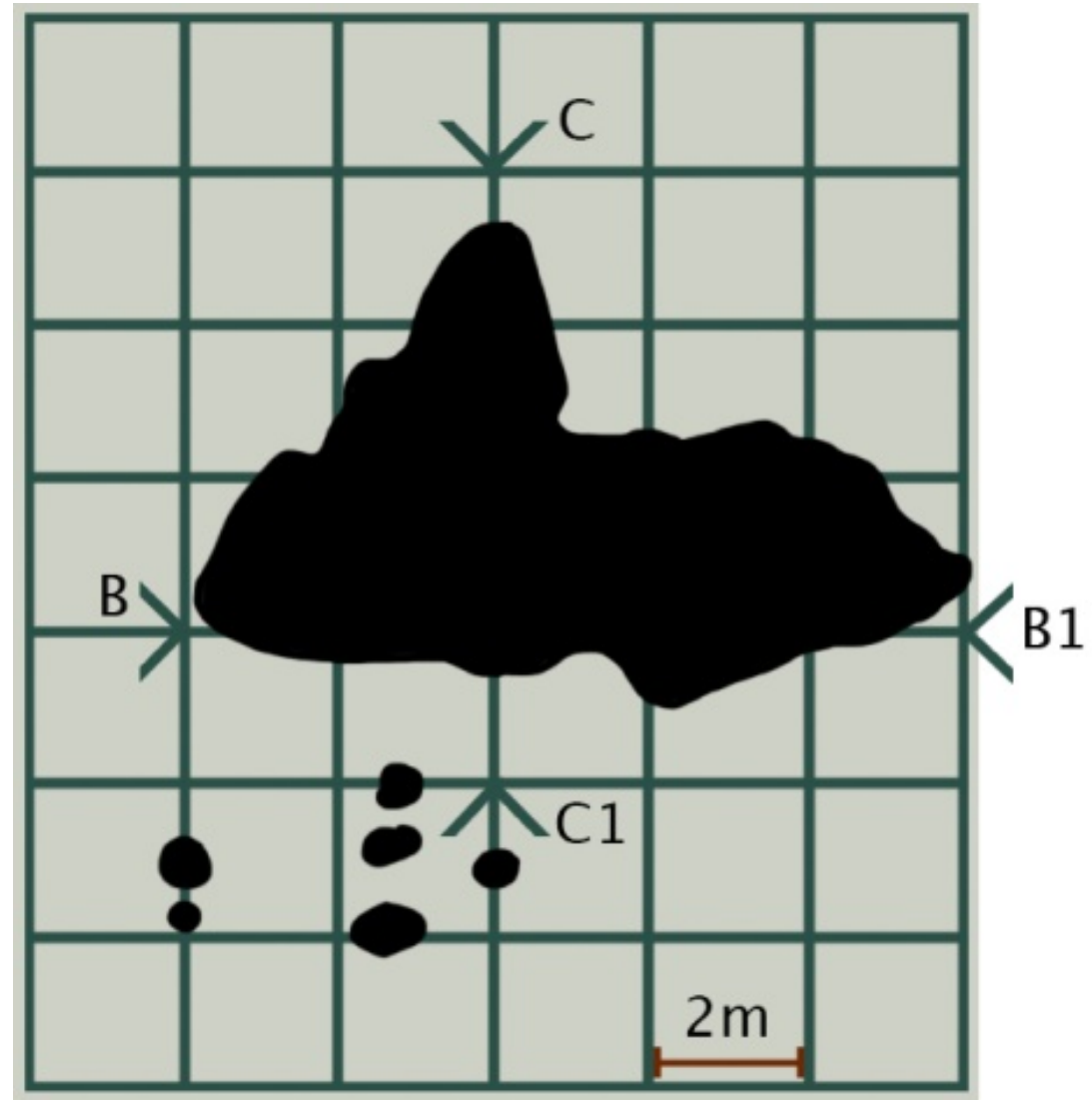

Figure 7. Neolithic sacrificial hearth and remains of wooden posts near the great sacrificial hearth: B-B $\mathrm{B}_{1}-$ east-west section of the large Neolithic sacrificial hearth; $\mathrm{C}-\mathrm{C}_{1}-$ north-south section of the large Neolithic sacrificial site hearth. Illustration by A. Butrimas

Figure 8. The reconstruction of wooden posts and sacrificial hearth. Sketch of reconstruction by R. Spelskyte 




Figure 9. The ornamentation of Neolithic and Bronze Age ceramic fragments from Donkalnis settlement. Illustration by A. Ruzienè
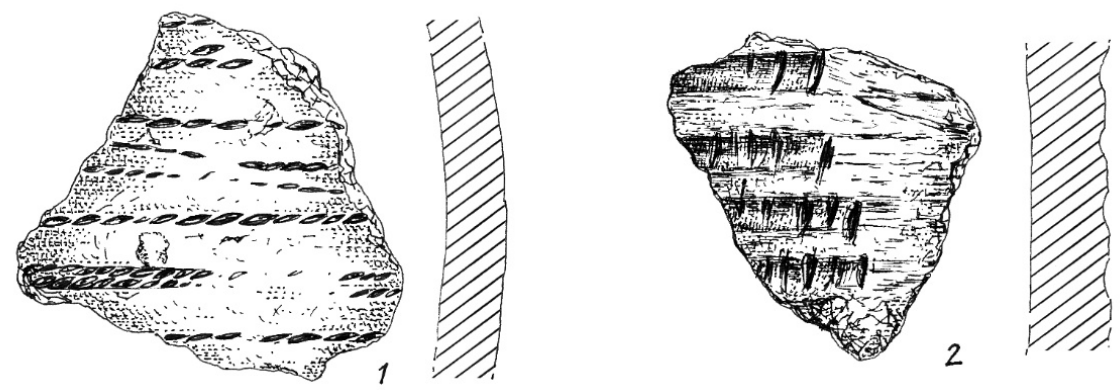

Figure 10. Potsherds from the Bronze Age Donkalnis settlement. Illustration by A. Ruzienè 

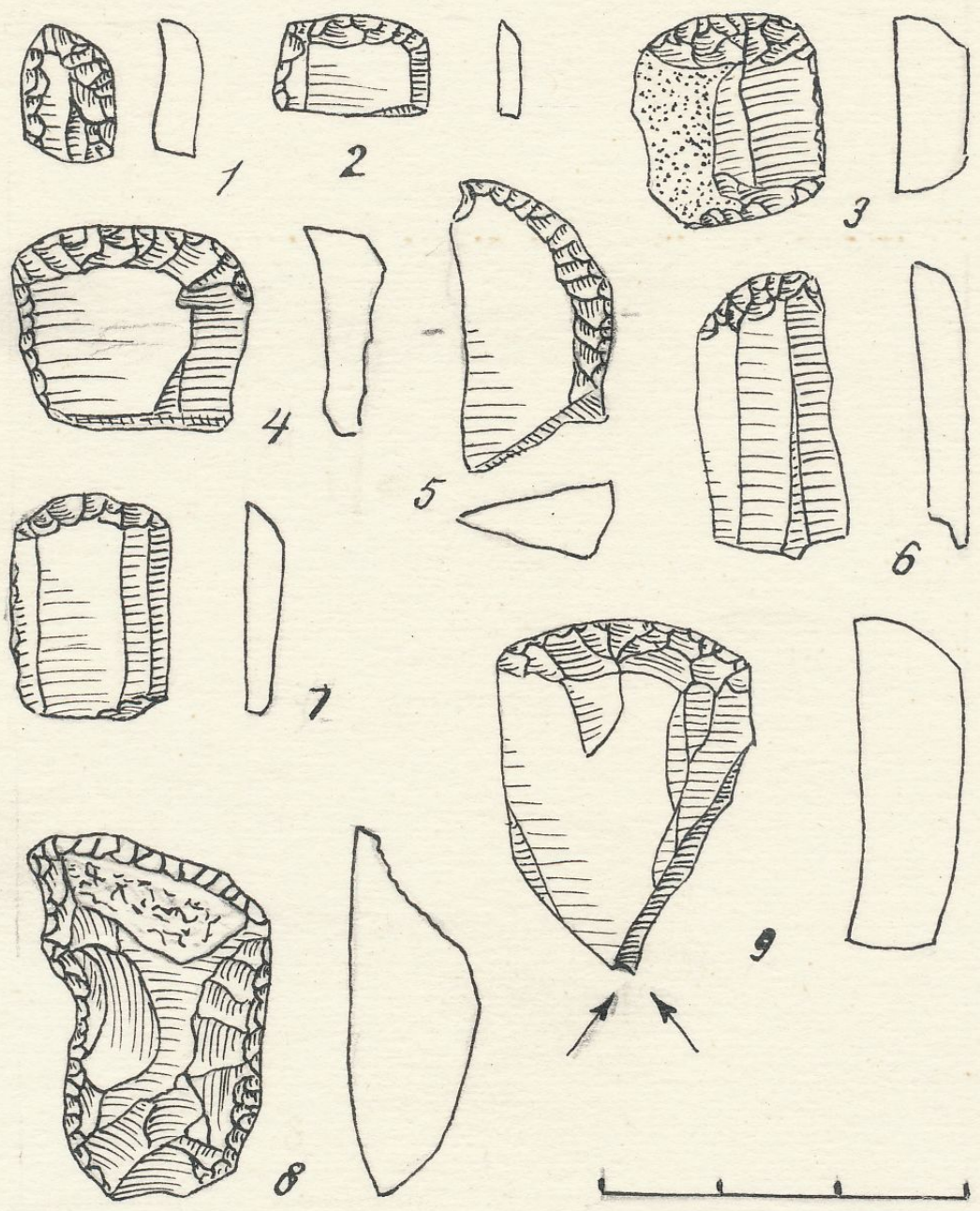

Figure 11. Flint artefacts from Donkalnis Mesolithic-Neolithic settlement cultural layer. Illustration by R. Rimantienè 

of Lake Biržulis (Lithuania) According to Archaeological, Linguistic and Historical Research

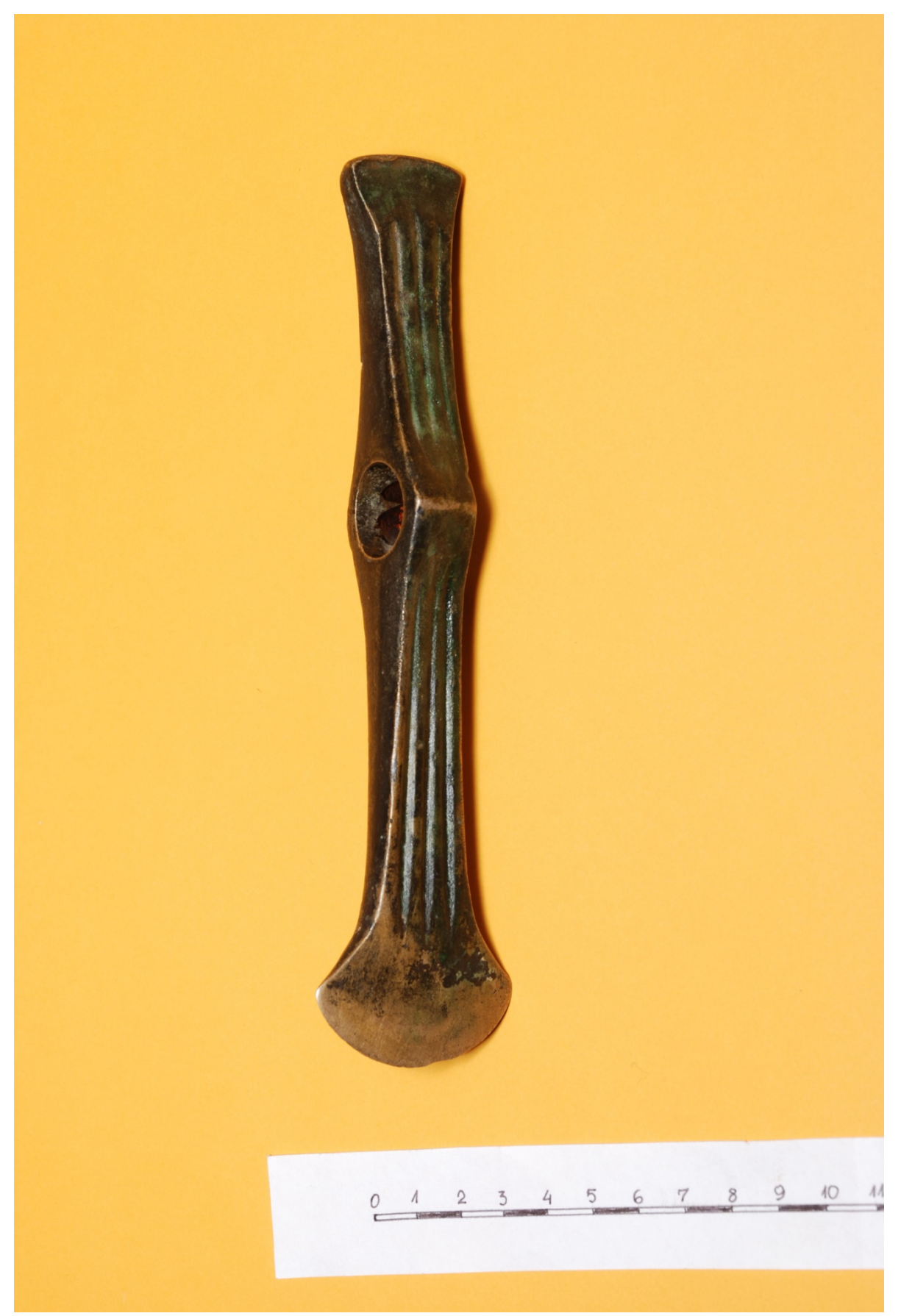

Figure 12. Bronze Age Nortikiai type axe from the Patiltis Hoard. Photo by J. Butrimaite 




Figure 13. Bronze pin from the Patilčiai Hoard. Photo by J. Butrimaitė

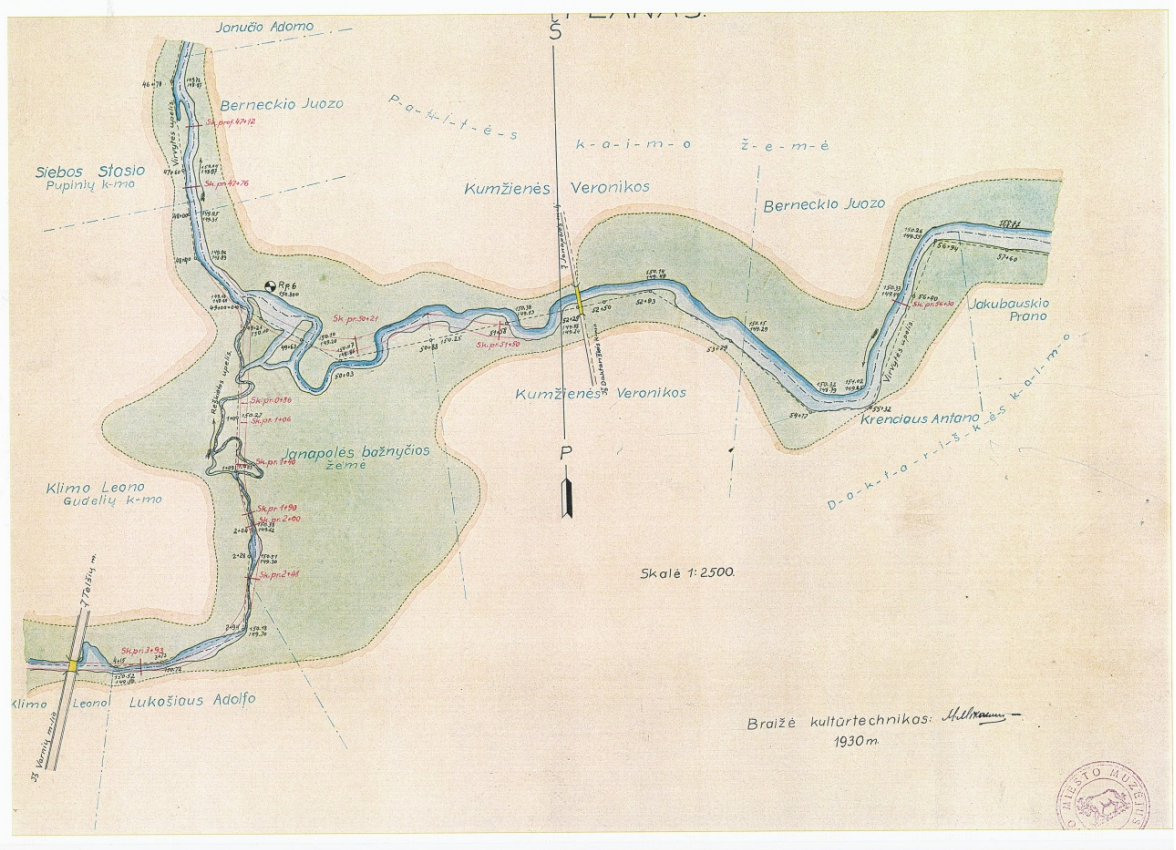

Figure 14. Sketch map of archaeological find sites with the bronze axe and pin offering places on the bank of the River Virvyte. Illustration by M. Mikalauskas, 1930 




Figure 15. Cross section of the bronze axe and pin offering places on the bank of the River Virvyte. Illustration by M. Mikalauskas, 1930 
Biržulis Lake North: Outline of the development of the ritualisation-sacralisation of the Donkalnis Ritual Ensemble

\begin{tabular}{|c|c|c|c|}
\hline $\begin{array}{c}\text { Mesolithic_Early Neolithic } \\
\text { Stage } 1 \\
6660-3500 \text { B.C. }\end{array}$ & $\begin{array}{l}\text { Late Neolithic } \\
\quad \text { Stage } 2 \\
3000-2100 \text { B.C. }\end{array}$ & $\begin{array}{c}\text { Early Metals' Age and Iron Age } \\
\text { Stage } 3 \\
2000 \text { B.C. }-300 \text { A.D. }\end{array}$ & $\begin{array}{c}\text { Historical Times } \\
\text { Stage } 4 \\
\text { Middle Ages-Early Modern } \\
\text { Period } \\
1294,1370,1421,1662 \\
\end{array}$ \\
\hline $\begin{array}{c}\text { Spiginas: Mesolithic graves } \\
\text { Donkalnis: Mesolithic, Middle } \\
\text { Neolithic graves } \\
\text { Kalniškès and Donkalnis } \\
\text { Mesolithic settlements } \\
\text { Grave of Seer and female } \\
\text { companion } \\
\text { Symbolic hearth in the Seer‘s } \\
\text { Grave } \\
\text { Ochre } \\
\text { Ochre pits - funerary feast and } \\
\text { sacrifice site } \\
\text { [23] }\end{array}$ & $\begin{array}{l}\text { Donkalnis Neolithic settlement } \\
\text { Late-Neolithic graves } \\
\text { Great sacrificial hearth, } \\
\text { Donkalnis } \\
\text { Remains of wooden poles near } \\
\text { the great sacrificial hearth / The } \\
\text { base of a timber post near the } \\
\text { Neolithic sacrificial hearth }\end{array}$ & $\begin{array}{c}\text { Gaigalinė Settlements } 1 \text { and } 2 \\
\text { Late-Neolithic- Early } \\
\text { Bronze-Age settlements } \\
\text { Offering fields } \\
\text { Stabakulis (Idol-Stone) Field } \\
\text { (Bishop's land register, 1662) } \\
\text { Stabinè (Idol) village (survives to } \\
\text { this day) } \\
\text { Patilčiai Bronze-Age sacrificial } \\
\text { site by the River Virvytė } \\
\text { (1700-1100 BC.) } \\
\text { Roman coin hoard from Janapole } \\
\text { (third century AD.) } \\
\text { Po alka (for the Shrine, the name } \\
\text { for a single dragnet of a lake, or } \\
\text { the catch from such a casting of } \\
\text { the net) (field research data, } \\
1980 \text { s) }\end{array}$ & $\begin{array}{c}\text { Širmė Hillfort } \\
\text { (early Middle Ages, pre-1413) } \\
\text { Viržuvėnai (Janapolè) offering or } \\
\text { temple-hill (early Middle Ages - } \\
\text { pre-fifteenth century) } \\
\text { The conversion of Žemaitija } \\
\text { Biržulis - the northern part of the } \\
\text { area was granted to the bishop of } \\
\text { Žemaitija in } 1421 \text { [6] } \\
\text { Pabiržulis boat and fishing nets } \\
\text { (ninth-twelfth cent.) } \\
\text { Viržuvenai } \\
\text { - site (1294-1370) } \\
\text { - village (16th-mid-19th century) } \\
\text { - church (mid-17th century.) } \\
\text { - church village, bishop's manor } \\
\text { (16th-19th century) } \\
\text { Old Viržuvėnai small ancient } \\
\text { pagan cemetery (6th-8th century } \\
\text { and 13th-15th century) }\end{array}$ \\
\hline \multicolumn{4}{|c|}{ Ancient-European-, Ancient Indo-European-, Baltic Toponyms, Hydronyms and their etymology } \\
\hline $\begin{array}{c}\text { Šermenys (funeral feast), } \\
\text { kermens - kūnas (body) [11] } \\
\text { Druja - flowing water [14] } \\
\text { Drawe - waters [12] } \\
\text { Druvis - believe [12], belief, firm } \\
\text { believer } \\
\text { Spiginas [14] } \\
\text { Spigsna - washing, sprinkling, } \\
\text { aspersion, cleansing, bathing [11] }\end{array}$ & $\begin{array}{c}\text { Biržulis - ritually pure }[17] \\
\text { Biržulis - divinity - } 1580[9,10] \\
\text { Donkalnis - the hill in the water }\end{array}$ & $\begin{array}{c}\text { Stabs, stabas (idol), stulpas } \\
\text { (pillar) [32] } \\
\text { Stabalkis [14] } \\
\text { Stabs - stone, idol [11] } \\
\text { Stabakulio laukas - Idol-Stone } \\
\text { Field } \\
\text { Alkalès / Offering fields } \\
\text { Stabine (The Idolry, place of } \\
\text { idols, or of the idol) (village lying } \\
\text { to the east of the Janapole } \\
\text { temple-hill) } \\
\text { Stabelauken, Stabingen [33] } \\
\text { Alks, elks - idol, (pagan) god } \\
\text { [11] } \\
\text { Stabalauks [11] - sustingęs (still, } \\
\text { torpid), sustiręs (stiff) }\end{array}$ & $\begin{array}{c}\text { Sirms - hoary, frosty-white, } \\
\text { armour [11] } \\
\text { Širmė funeral feast }[24,35] \\
\text { Sermen - penèjimai / feeding [11] } \\
\text { Alkalè - šventoji pieva / Offering } \\
\text { field } \\
\text { Alka, alkas [12] - a sacred grove, } \\
\text { idol, sacrificial hill, sacrifice, a } \\
\text { small tree-covered hill, a (pagan) } \\
\text { god }\end{array}$ \\
\hline
\end{tabular}

\section{Conclusions}

The Islands of Donkalnis and Spiginas were very clearly visible in the landscape. They were socially very important for local societies - the members of society permanently returned to them and permanently coming back was a very important part of social memory and taking part in shared rituals strengthened their community identity.

This may have determined the slow monumentalization of Donkalnis and, later, of a very narrow westerly strip of land with prehistoric monuments. These connections remained unbroken, deepening over time and changing to become very important ritual sites during the Metals' period and even as late as the official Conversion to Christianity.

The late official conversion of Žemaitija which began after 1413 saw the donation of part of this part of the lake to the bishops of Žemaitija, as we see from episcopal land registers (16th-17th century). These registers and data from field research undertaken in 1978-1990 and linguistic-etymological studies (based on toponyms, hydronyms, fishing terminology, recorded from old lake fishermen) provide material for the further interpretation of the development of these archaeological sites during their long chronology.

\section{REFERENCES}

[1] J. Richards. Stonehenge, 2015.

[2] M. P. Pearson, J. Pollard, C. Richards, J. Thomas, C. Tilloy, K. Welham. Der Griff nach den Sternen Tagungen des Landesmuseum für Vorgeschichte Halle (Saale), 01/05, 397-415, 2010.

[3] R. J. Harrison. Stonehenge in the Early Bronze Age. De Griff nach den Sternen, 417-437, 2010. 
[4] V. Žulkus. Vakarinių Žemaičiu žemès XIII-XIV a. Biržulio baseino kompleksiniu tyrinèjimu dešimtmetis. Vilnius, 26-30, 1987.

[5] Lietuvos TSR istorijos šaltiniai. 1, Vilnius, 1955.

[6] I. Plečkytė, A. Katilius. Dèl Biržulio ežero priklausomybès. Biržulio baseino kompleksiniu tyrinejjimu dešimtmetis. Vilnius, 69-71, 1987.

[7] A. Butrimas, E. Meilus. Iš Viržuvėnų (Janapolès) istorijos. Biržulio baseino kompleksiniu tyrinëjimu dešimtmetis. Lietuvos TSRS istorijos etnografijos muziejus, Vilnius, 78-88, 1987.

[8] A. Brückner. Starożytna Litwa. Ludy i Bogi. Warszawa, 1904.

[9] J. Lasickis. Apie Žemaičiu dievus. Vaga, Vilnius, 1969.

[10] W. A. Jaskiewicz. Study in Lithuanian Mythology, Jan Łasicki's Žemaitijan Gods. Studi Baltici 9, 65-108, 1952.

[11] V. Mažiulis. Prūsu kalbos etimologinis žodynas, Mokslo ir enciklopediju leidybos centras, Vilnius, 2013.

[12] V. Toporov. Prusskij jazyk. Slovar, 1. Nauka, Moskva, 266-267, 1975.

[13] V. Toporov. Prusskij jazyk. Slovar, 2, 1980.

[14] A. Vanagas. Lietuviu hidronimu etimologinis žodynas. Mokslas, Vilnius, 1981.

[15] C. Lévi-Strauss. Antropologie structurale. Plon, Paris, 1958.

[16] C. Lévi-Strauss. Antropologija modernaus pasaulio problemu akistatoje. Žara, Vilnius, 2015.

[17] T. V. Gamkrelidze, V. V. Ivanov. Indo-European and Indoeuropeans, II. Publishing house of the Tbilisi State University, Tbilisi, 1984.

[18] W. Mannhard. Lettopreussische Götterlehre. Riga, 1936.

[19] N. Vèlius (ed.) Baltu religijos ir mitologijos šaltiniai, 4. Vilnius, 2005.

[20] K. Būga. Rinktiniai raštai. Vilnius, 3, 1961.

[21] M. Rudzīte. Somugriskie hidronīmi Latvijas PSR teritorijā. Latviešu leksikas attīstība. Rīga, 175-197, 1968.

[22] B. Bramanti, M. G. Thomas, W. Haak, M. Unterlaender, P. Jores, K. Tambets, I. Antanaitis-Jacobs, M. N. Haidle, R. Jankauskas, C. J. Kind, F. Lueth, T. Terberger, J. Hiller, S. Matsumara, P. Forster, J. Burger. Genetic Discontinuity between local Hunter-Gatheress and Central Europe's first farmers. Science express, 1-10, 2009.

[23] A. Butrimas. Donkalnio ir Spigino mezolito-neolito kapinynai. Seniausi laidojimo paminklai Lietuvoje. Vilnius Academy of Arts Press, Vilnius, 2012.

[24] N. Gurina. Oleneostrovskij mogil'nik. Materialy $i$ issledovanija po archeologii SSSR 47, 107-124, 1956.

[25] F. Zagorskis. Zveijnieku akmens laikmena kapulauks. Zinatne, Rìga, 1987.

[26] M. Gimbutas. Culture Change in Europe at the Starto $f$ the Second Millenium B. C.: A Contribution of the Indo-European problem. Selected Papers of the Fifth International Congress of Anthropological and Ethnological Sciences. Philadelphia, 540-552, 1956.

[27] W. Haak, I. Lazaridis, N. Patterson, N. Rohland, S. Mallick, B. Llamas, G. Brandt, S. Nordenfelt, E. Harney, K. Stewardson, O. Fu, A. Mittnik, E. Bánfi, Ch. Economou, M. Francken, S. Friederich, R. G. Pena, F. Hallgrent, V. Khartanovich, A. Khokhlov, M. Kunst, P. Kuznetsov, H. Meller, O. Mochalov, V. Moiseyev, N. Nieklisch, S. L. Pichler, R. Risch, M. Rojo Guerra, C. Roth, N. Szécsényi, J. Wahe, M. Meyer, J. Krause, D. Brown, D. Anthony, A. Cooper, K. W. Alt, D. Reich. Nature, 522, 1-140, 2015.

[28] M. Gimbutas. The three waves of the Kurgan People in to Old Europe, 4500-2500 B. C. Archives Suisse d'anthropologie generale, 43:2, 113-137, 1979.

[29] D. Monasterski. Pojezierze Mazurskie u schyku neolitu i na poczatku epochi brazu w świetle zespolów typu Zabie-Szestno. Warszawa, 2009.

[30] R. Rimantienè. Nida senuju baltu gyvenvietè. Vilnius, 1989.

[31] A. Žilinskaitè. Tšcineco kultūra Lietuvoje. Lietuvos archeologija 41, 9-44, 2015.

[32] V. Dambe. Saknes bali-, pali- (skaņu mijā) ar slapjas vietas nozīmi vietvārdos. R. Grabis (ed.) Veltijums akademikum Janim Endzelinam: 1873-1973, Zinatne, Riga, 1972.

[33] G. Gerulis. Die altpreußishen Ortsnamen. Vereinigung wissenschaftlicher verleger Berlin und Leipzig, 1922.

[34] G. H. F. Nesselmann. Die Sprache der alten Preussen: an ihren Ueberresten erläutert. Reimer, Berlin, 1845.

[35] G. H. F. Nesselmann. Thesaurus linguae prussicae. Der preussische Vocabelvorrath, soweit derselbe bis jetzt ermittelt worden ist, nebst Zugabe einer Sammlung urkundlich beglaubigter Localnamen, F. Dümmler, Berlin, 1873. 